\title{
Branched Poly(ethylene imine)s as Anti-algal and Anti-cyanobacterial Agents with Selective Flocculation Behavior to Cyanobacteria over Algae
}

\author{
Premysl Mikula, Marie Mlnarikova, Haruko Takahashi, Pavel Babica, Kenichi Kuroda, \\ Ludek Blaha, and Iva Sovadinova*
}

Poly(ethylene imine)s (PEIs) have been widely studied for biomedical applications, including antimicrobial agents against potential human pathogens. The interactions of branched PEIs (B-PEIs) with environmentally relevant microorganisms whose uncontrolled growth in natural or engineered environments causes health, economic, and technical issues in many sectors of water management are studied. B-PEls are shown to be potent antimicrobials effective in controlling the growth of environmentally relevant algae and cyanobacteria with dual-functionality and selectivity. Not only did they effectively inhibit growth of both algae and cyanobacteria, mostly without causing cell death (static activity), but they also selectively flocculated cyanobacteria over algae. Thus, unmodified B-PEls provide a cost-effective and chemically facile framework for the further development of effective and selective antimicrobial agents useful for control of growth and separation of algae and cyanobacteria in natural or engineered environments.

\section{Introduction}

Green algae and cyanobacteria (also known as blue-green algae) are essential in providing oxygen and food for other organisms. However, uncontrolled growth of these microbial species in natural or engineered environments causes health, economic, and technical issues in many sectors of water management including water distribution systems for industrial manufactures, agriculture, and drinking water supplies. ${ }^{[1]}$ The presence of algae and cyanobacteria in water creates nuisance conditions such as unsightly blooms (dense accumulations

Dr. P. Mikula, M. Mlnarikova, Dr. P. Babica, Prof. L. Blaha,

Dr. I. Sovadinova

Research Centre for Toxic Compounds in the Environment (RECETOX)

Faculty of Science

Masaryk University

Kamenice 5, CZ-62500 Brno, Czech Republic

E-mail: sovadinova@recetox.muni.cz

Dr. H. Takahashi, Prof. K. Kuroda

Department of Biologic and Materials Sciences

School of Dentistry

University of Michigan

1011 North University Avenue, Ann Arbor, MI 48109, USA

The ORCID identification number(s) for the author(s) of this article can be found under https://doi.org/10.1002/mabi.201800187.

DOI: 10.1002/mabi.201800187 of cells), unpleasant taste and odors, turbidity, and clogging of filters. Moreover, cyanobacterial blooms in water reservoirs can produce toxins, which represent ecological and human health hazards. ${ }^{[2]}$ In addition, cooling water systems such as, for example, cooling towers used in power stations, provide a favorable environment for the growth of algae and cyanobacteria. ${ }^{[3]}$ If uncontrolled, the growth of algae and cyanobacteria leads to formation of robust biofilms and causes fouling, which compromises equipment performance and promotes corrosion. ${ }^{[4]}$ Thus, the prevention, management, and mitigation of uncontrolled growth of algae and cyanobacteria have been of great concern for public health and industrial sectors.

The natural growth of algal and cyanobacterial cells has been controlled by using mechanical, physical, biological, or chemical methods, ${ }^{[2,5]}$ which directly inhibit their cell growth and/or remove them from natural and artificial aquatic environments. Particularly, algae or cyanobacteria from various types of water have been removed by algaecides and/or flocculation, which is also of extreme importance to ensure continual maintenance of a high level quality of water. ${ }^{[6]}$ However, the growth control and removal of algae and cyanobacteria have been challenging due to the low efficiency of current methods, non-target toxicity of traditional approaches, and alteration of ecosystems. ${ }^{[2,7]}$

In this study, we take a step forward to address these concerns on uncontrolled growth of algae and cyanobacteria. We demonstrate that a class of cationic synthetic polymers, branched poly(ethylene imine)s (B-PEIs) have dual-functionalities that can 1) inhibit growth of algae and cyanobacteria and 2) selectively flocculate one phototrophic microbial species over another one. A set of B-PEIs have been reported to exhibit potent antimicrobial activity against biomedically relevant bacteria including Gram-positive bacterium Staphylococcus aureus $(S A)$ and Gram-negative bacterium Escherichia coli (EC). ${ }^{[8]}$ We have previously demonstrated that the B-PEIs displayed enhanced growth-inhibitory activity of $S A$ over $E C C^{[8 b]}$ indicating that the activity of B-PEIs may be dependent on the cell wall structures of bacteria. On the other hand, PEIs are generally used for the flocculation of bacterial sludge to improve the efficiency of dewatering in wastewater treatment processes. ${ }^{[9]}$ 
PEIs have also shown potential as flocculating agents as well as a retention and drainage aid in the paper industry. ${ }^{[10]}$ Based on these functionalities of PEIs through interactions with bacteria, we hypothesize that PEIs would be potent antimicrobial and flocculating agents against algae and cyanobacteria.

To test the hypothesis, we examined the ability of B-PEIs with different molecular weights (MWs) to interact with algae and cyanobacteria. We selected freshwater green algae Chlamydomonas reinhardtii $(C R)$ and Desmodesmus quadricauda (DQ), and cyanobacteria Synechococcus elongatus (SE) and Microcystis aeruginosa (MA) as model species for this study. Despite the broad range of biomedical and industrial applications of PEIs, ${ }^{[11]}$ the investigation on the antimicrobial and flocculation activities of PEIs against algal and cyanobacterial species has been very limited so far. We assessed the B-PEIs for their ability to induce flocculation of these microorganisms in individual cultures and in their mixture. The results in this study provide a new insight into the potential of synthetic polymers for their use in control of algae and cyanobacteria at homes, industrial settings, and natural environments.

\section{Results and Discussions}

\subsection{Chemical Structure and Properties of B-PEls}

We investigated the anti-algal and anti-cyanobacterial properties of B-PEIs (Figure 1E) with the number of average molecular weights $\left(\overline{\mathrm{M}}_{n}\right)$ of $470\left(\mathrm{~B}-\mathrm{PEI}_{0.5}\right), 1100\left(\mathrm{~B}-\mathrm{PEI}_{1.1}\right)$, and 12000 $\left(\mathrm{B}-\mathrm{PEI}_{12}\right)$ (Table $\mathrm{S} 1$, Supporting Information), which were experimentally determined by gel permeation chromatography (GPC). ${ }^{[8 b]} \overline{\mathrm{M}}_{n}$ and $\overline{\mathrm{M}}_{w}$ values were different from the MWs reported by the supplier $(600,1800$, and 10000 , respectively). We have also previously determined the $\mathrm{pK}_{\mathrm{a}}$ values of primary and secondary $\left(\mathrm{pK}_{\mathrm{a} 1}\right)$ and tertiary $\left(\mathrm{pK}_{\mathrm{a} 2}\right)$ amine groups of these B-PEIs by potentiometric titration. Their $\mathrm{pK}_{\mathrm{a} 1}$ and $\mathrm{pK}_{\mathrm{a} 2}$ values are between 9.0 and 9.4 and 5.8 and 6.2, respectively. ${ }^{[8 b]}$ Therefore, the primary and secondary amine groups of B-PEI were protonated or cationic (ammonium) in a neutral $\mathrm{pH}$ environment, while the tertiary amine groups were in a basic amine form.

\subsection{Growth Inhibition by B-PEIs}

We evaluated the antimicrobial activity of B-PEIs against algae $(D Q$ and $C R)$ and cyanobacteria ( $S E$ and $M A)$ using the standardized optical density-based growth inhibition test. ${ }^{[12]}$ The B-PEIs showed a concentration-dependent inhibitory effect against all species (Figure 1B-D). The concentration causing complete $(100 \%)$ inhibition of algal or cyanobacterial growth was found for all polymers and species, except for $\mathrm{B}-\mathrm{PEI}_{12}$ against $\mathrm{DQ}$, which showed maximal $\approx 40-47 \%$ growth inhibition (Table 1). The effective growth inhibitory concentrations of tested B-PEIs (Table 1) are comparable with those of other chemical agents with potent anti-algal or anticyanocidal activity, such as copper sulfate, hydrogen peroxide, or phthalocyanines, which show the $72-96 \mathrm{~h} \mathrm{IC}_{50}$ values of 0.1 to
$0.3 \mu \mathrm{g} \mathrm{mL}{ }^{-1}{ }^{[13]}$ The $\mathrm{IC}_{50}$ values did not significantly change with the exposure time (Figure 1F and Table S2, Supporting Information).

Surprisingly, even though the tested microorganisms greatly differ ${ }^{[14]}$ in the cell type (prokaryotic vs eukaryotic), cell structure (size, surface, volume, cell wall, and membrane composition), and cell doubling time (Table S3, Supporting Information), the susceptibility ( ${ }_{72 \mathrm{~h}} \mathrm{IC}_{50}$ values $=0.1$ to $0.6 \mu \mathrm{g} \mathrm{mL} \mathrm{m}^{-1}$ ) of algae $C R$ and cyanobacteria $S E$ and $M A$ to the B-PEIs was well comparable (Table 1 ). On the other hand, algal $D Q$ cells were more resistant to B-PEIs (from 4 to 20 times higher $\mathrm{IC}_{50}$ values than those for other species). The difference in sensitivity may be attributed to several factors including the cell wall structure or colony formation. The cell wall of $D Q$ is primarily composed of several hemicellulosic and sporopolleninic layers, ${ }^{[15]}$ which provide a robust biopolymer network. When B-PEIs bind to the cell surface of $D Q$, the cell wall may be a physical barrier which traps B-PEIs and prevents them to access to the cytoplasmic membranes or the inside of cells. The cell walls of other studied species consist of glycoproteins $(C R),{ }^{[16]}$ peptidoglycans $(S E, M A),{ }^{[17]}$ or lipopolysaccharides $(S E, M A)^{[17]}$ which may in turn be more sensitive to the B-PEIs. Additionally, $D Q$ cells form relatively large colonies of two to eight ellipsoidal cells joined laterally (so-called coenobia, Table S3 and Figure S1, Supporting Information). This is in contrast to other tested phototrophic microorganisms which are unicellular species and do not form colonies under the experimental conditions used in this study. Coenobium has a smaller surface-to-volume ratio which might reduce access of B-PEIs to the individual cells and increase their resistance compared to solitary cells.

Although the elucidation of molecular mechanism of B-PEIs for their growth-inhibitory effects is beyond the scope of this study, we hypothesize that the B-PEIs act by interacting with the cell wall and/or membranes as proposed for their effects on human pathogenic bacteria. ${ }^{[8]}$ The $\mathrm{pK}_{\mathrm{a}}$ values of primary and secondary amine groups of the B-PEI used in this study are $9.0-9.4^{[8 b]}$ suggesting that the primary and secondary amine groups of B-PEI are protonated or cationic (ammonium) at a neutral $\mathrm{pH}$ of the assay medium. On the other hand, in general, the cell surfaces of algae and cyanobacteria are negatively charged due to the de-protonation of carboxyl and/or sulfate groups in the algal cell walls ${ }^{[18]}$ as well as the anionic components of peptidoglycan including murein in the cyanobacterial cell walls ${ }^{[17 c]}$ and/or extracellular polysaccharide glycocalyx layer surrounding cell walls. ${ }^{[17 \mathrm{~d}]}$ Therefore, the B-PEIs are likely to bind to the algal and cyanobacterial cell surfaces by the electrostatic interactions. After interacting with the cell wall and crossing it, the B-PEIs might enter the cells for internal targets. Previous studies showed that cationic poly(amidoamine) dendrimers (PAMAM), which have branched structures with amine terminal groups similar to B-PEIs, interact with and cross cell wall, ${ }^{[19]}$ bind to the cell membrane and subsequently internalize into the treated algal and cyanobacterial cells. ${ }^{[19 c]}$ While mitochondria were the most affected organelles by PAMAM in the green algae, a diffuse intracellular distribution was showed in cyanobacteria. ${ }^{[19 c]}$ Similarly, our data suggest that the B-PEIs are likely to exhibit their inhibitory effect by the similar way as PAMAM. 
A.

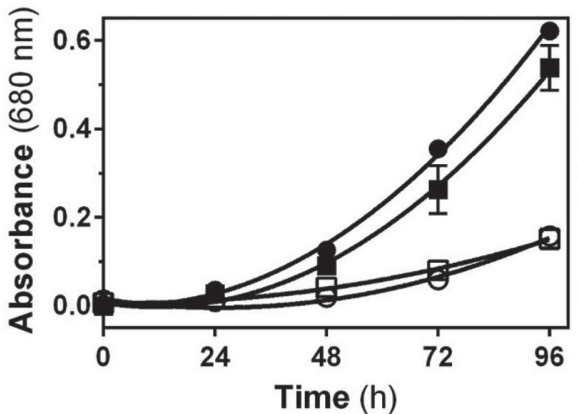

C.

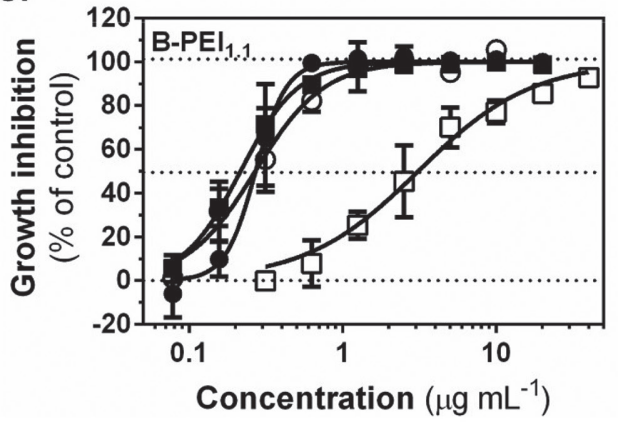

B.

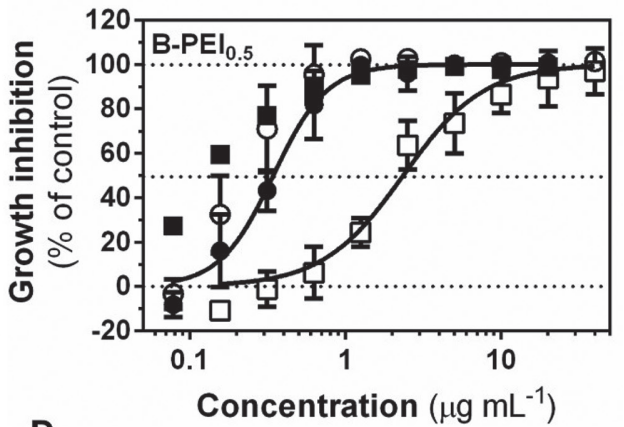

D.

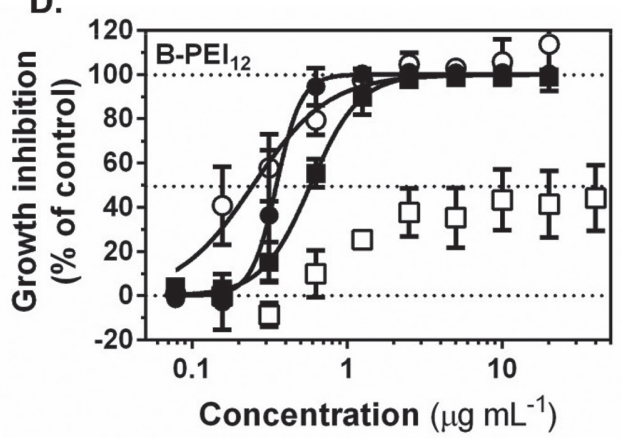

$\longrightarrow \mathrm{CR} \rightarrow \mathrm{DQ} \longrightarrow \mathrm{SE} \longrightarrow \mathrm{MA}$

E.

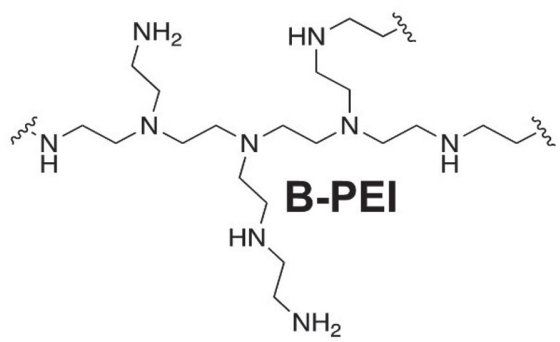

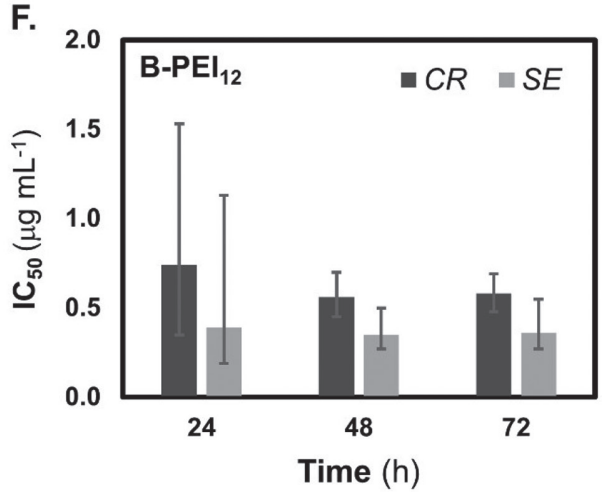

Figure 1. The effects of B-PEls on the growth of freshwater green algae and cyanobacteria. A) The specific growth curve of algae Chlamydomonas reinhardtii $(C R)$ and Desmodesmus quadricauda $(D Q)$ and cyanobacteria Synechococcus elongatus (SE) and Microcystis aeruginosa (MA) cultures. B-D) The effects of B-PEls on the growth of algae ( $C R$ and $D Q$ ) and cyanobacteria (SE and MA) after 72-h exposure. Data are expressed as a percentage of a non-treated control and presented as means (SD). E) Chemical structure of B-PEls. F) The growth inhibitory effect of B-PEls did not change with the exposure time as presented for B-PEI 12 and algae $C R$ and cyanobacteria $S E(p>0.05$, one-way ANOVA with Dunnett's method). Data are presented as geo-mean of $\mathrm{IC}_{50}$ values of at least three independent experiments with $95 \% \mathrm{Cl}$.

\subsection{Algicidal/Cyanocidal Activity of B-PEls}

To assess the ability of B-PEIs to cause a cell death, the autofluorescence of intracellular photosynthetic pigments of algae and cyanobacteria was monitored during the exposure to the B-PEIs. In general, the autofluorescence intensity of viable algal and cyanobacterial cells increases with time as these cells proliferate, and the number of fluorescent cells increases. In the presence of antimicrobial agents, no increase or reduction in the autofluorescence intensity relative to the value of initial inoculation is indicative of the significant cytotoxicity of agents to these cells causing a reduction of photosynthesis, a stoppage of proliferation (growth inhibition), and/or cell death. ${ }^{[20]}$ Specifically, a reduction of autofluorescence intensity decreasing below the value of the initial inoculation suggests algicidal/cyanocidal effect.

In addition to growth-inhibitory effect, the B-PEIs acted as algicidal agents and reduced the autofluorescence intensity of $C R$ after 24-h treatment below the initial value before the treatment (Figure 2A for B-PEI 12 , Figure S2A, Supporting Information, for B-PEI $\mathrm{I}_{0.5}$ and $\mathrm{B}-\mathrm{PEI}_{1.1}$ ) with minimal cidal concentration after 72-h exposure ${ }_{72} \mathrm{MCC} \geq 1.3 \mu \mathrm{g} \mathrm{mL} \mathrm{L}^{-1}$ (Table 1). Microscopic assessment also revealed that the B-PEIs inhibited cell motility of $C R$ immediately during the first hour of 
Table 1. Summary of anti-algal and anti-cyanobacterial activities of B-PEIs and PPI-DEN.

\begin{tabular}{|c|c|c|c|c|c|c|c|}
\hline & Species & Environmental relevance & Activity & $\mathrm{B}-\mathrm{PEI}_{12}$ & B-PEI 1.1 & B-PEI 0.5 & PPI-DEN \\
\hline \multirow{6}{*}{$\begin{array}{l}\text { Green algae- } \\
\text { eukaryotic cell type }\end{array}$} & \multirow{3}{*}{$\begin{array}{c}C R \\
\text { Volume }^{c)}=113-904 \mu \mathrm{m}^{3} \\
D T^{d)}=19 \mathrm{~h}\end{array}$} & \multirow{3}{*}{$\begin{array}{l}\text { A common species of } \\
\text { extensive water blooms } \\
\text { A model organism for anti- } \\
\text { algal tests and biofouling }\end{array}$} & ${ }_{72 h}\left|\mathrm{C}_{50} /{ }_{72 h}\right| \mathrm{C}_{100}^{\mathrm{a})}\left(\mu \mathrm{g} \mathrm{mL}^{-1}\right)$ & $0.6 / 2.5$ & $0.2 / 1.3$ & $0.1 / 1.3$ & $0.2 / 2.5$ \\
\hline & & & $\left.{ }_{72 h} \mathrm{MCC}^{\mathrm{b}}\right)\left(\mu \mathrm{g} \mathrm{mL}^{-1}\right)$ & 2.5 & 1.3 & 1.3 & 2.5 \\
\hline & & & Aggregation/flocculation & -- & -- & - & - \\
\hline & \multirow{3}{*}{$\begin{array}{c}D Q \\
\text { Volume }=64-462 \mu \mathrm{m}^{3} \\
\text { DT }=24 \mathrm{~h}\end{array}$} & \multirow{3}{*}{$\begin{array}{l}\text { A common species of } \\
\text { extensive water blooms } \\
\text { A model organism for anti- } \\
\text { algal tests and biofouling }\end{array}$} & ${ }_{72} \mathrm{IC}_{50} /{ }_{72 \mathrm{~h}} \mathrm{I} \mathrm{C}_{100}\left(\mu \mathrm{g} \mathrm{mL}^{-1}\right)$ & $2.5-40^{\mathrm{e})} />40$ & $3.4 / 40$ & $2.6 / 20$ & $2.7 / 10$ \\
\hline & & & ${ }_{72 h} \mathrm{MCC}\left(\mu \mathrm{g} \mathrm{mL}^{-1}\right)$ & $>40$ & $>40$ & $>40^{f)}$ & 10 \\
\hline & & & Aggregation/flocculation & -- & -- & -- & - \\
\hline \multirow{6}{*}{$\begin{array}{l}\text { Cyanobacteria- } \\
\text { prokaryotic cell type }\end{array}$} & \multirow{3}{*}{$\begin{array}{c}S E \\
\text { Volume }=0.1-2 \mu \mathrm{m}^{3} \\
\text { DT }=14 \mathrm{~h}\end{array}$} & \multirow{3}{*}{$\begin{array}{l}\text { A common species in } \\
\text { freshwater sources } \\
\text { A model organism for } \\
\text { anti-cyanobacterial tests }\end{array}$} & ${ }_{72 h} \mathrm{I} \mathrm{C}_{50} / 72 \mathrm{~h} \mathrm{C}_{100}\left(\mu \mathrm{g} \mathrm{mL} \mathrm{L}^{-1}\right)$ & $0.4 / 0.6$ & $0.3 / 0.6$ & $0.4 / 1.3$ & $0.2 / 0.6$ \\
\hline & & & ${ }_{72 h} \mathrm{MCC}\left(\mu \mathrm{g} \mathrm{mL} L^{-1}\right)$ & $>40 \mathrm{~g})$ & $>40^{h)}$ & $>40$ & $>40$ \\
\hline & & & Aggregation/flocculation & +++ & + & + & + \\
\hline & \multirow{3}{*}{$\begin{array}{c}\text { MA } \\
\text { Volume }=22-113 \mu \mathrm{m}^{3} \\
\text { DT }=27 \mathrm{~h}\end{array}$} & \multirow{3}{*}{$\begin{array}{l}\text { A bloom-forming species } \\
\text { capable of producing the } \\
\text { cyanotoxins (microcystins) }\end{array}$} & ${ }_{72 h}\left|C_{50} / 72 h\right| C_{100}\left(\mu \mathrm{g} \mathrm{mL}^{-1}\right)$ & $0.2 / 1.3$ & $0.3 / 1.3$ & $0.2 / 1.3$ & $0.3 / 2.5$ \\
\hline & & & ${ }_{72 h} \mathrm{MCC}\left(\mu \mathrm{g} \mathrm{mL}^{-1}\right)$ & $>40^{i)}$ & $>40$ & $>40$ & $>40$ \\
\hline & & & Aggregation/flocculation & +++ & ++ & - & - \\
\hline
\end{tabular}

a) The concentration causing $50 \%$ or $100 \%$ inhibition after 72 -h exposure; b) Minimal cidal concentration after $72-\mathrm{h}$ exposure; ${ }^{\mathrm{c}}$ Calculated based on geometric models for phytoplankton, ${ }^{[14]}$ the size parameters from Protist Information Server (http://protist.i.hosei.ac.jp/); ${ }^{d}$ Doubling time (DT) under the conditions of this study; ${ }^{\text {e) } A ~ c l e a r ~ c o n-~}$ centration-dependent effect at the concentrations of $0.3-2.5 \mu \mathrm{g} \mathrm{mL^{-1 }}$ was followed by a plateau value of growth inhibition of about $40-47 \%$ observed along the concentra-

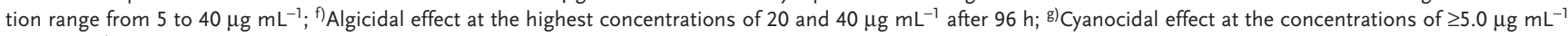

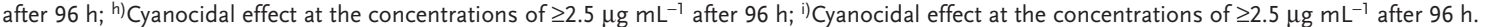

exposure to concentrations $\geq 2.5 \mu \mathrm{g} \mathrm{mL} \mathrm{m}^{-1}$ (data not shown). The autofluorescence intensity decreased close to the level of culture medium within the first $24 \mathrm{~h}$ and did not change up to $72 \mathrm{~h}$ of exposure, indicating that the B-PEIs caused a death of most $C R$ cells within the first $24 \mathrm{~h}$. Fluorescent images confirmed that the autofluorescence of individual $C R$ cells was significantly reduced (chlorosis) as compared to the controls after 72-h treatment (Figure 2B for B-PEI ${ }_{12}$, Figure S2B, Supporting Information, for $\mathrm{B}-\mathrm{PEI}_{0.5}$ and $\mathrm{B}-\mathrm{PEI}_{1.1}$ ). It was accompanied also by a significant cellular damage, as many cells were deformed and fragmented. These results suggest that the B-PEIs not only inhibited the growth of algae $C R$ (algistatic activity), but also caused cell death. This algicidal effect occurred at higher concentrations than those causing significant growth inhibition (Table 1). The quick action and cell deformation may indicate that the PEIs act by binding to the cell wall of $C R$ and crossing it, subsequently by destabilizing and permeabilizing the cell membrane, which leads to cell death. Our suggestion is supported by literature, because PEIs are the well-known permeabilizers of different type cells including bacteria. ${ }^{[21]}$

In contrast, the B-PEIs inhibited the growth of other phototrophic microorganisms mostly without causing cell death

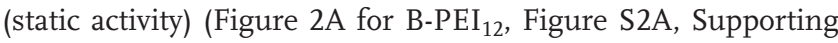
Information, for $\mathrm{B}-\mathrm{PEI}_{0.5}$ and $\left.\mathrm{B}-\mathrm{PEI}_{1.1}\right)$. Algae $D Q$ as well as cyanobacteria $S E$ and $M A$ exposed to B-PEIs remained mostly intact and brightly autofluorescent (Figures S1 and S3, Supporting Information) although their growth was inhibited, suggesting they are more resistant to cidal activity of B-PEIs. The mechanism responsible for higher susceptibility of $C R$ to the B-PEIs than that for other studied species remains unclear. Similarly to the growth-inhibitory effect, the explanation might be in species-dependent differences in cell wall and membrane composition (Table S3, Supporting Information).

\subsection{Selective Aggregation and Flocculation of Cyanobacterial Cells}

B-PEIs with higher MW (more than $10 \mathrm{kDa}$ ) were reported to intensively flocculate cyanobacterium Anabaena flos-aquae $(A F),{ }^{[22]}$ bacteria in sludges ${ }^{[9 a]}$ as well as Gram-negative anaerobic bacteria Schewanella oneidensis (SO) MR-1.[23] However, the previous studies reported only on the flocculation of individual microorganism of interest, but the effects of B-PEIs on different cyanobacteria and algae, which have different cell sizes, cell wall composition, and surface properties, were not compared under the same conditions. Our study demonstrated that the aggregation and flocculation activities of B-PEIs were selective to the cyanobacteria over the algae tested. B-PEI ${ }_{12}$ did effectively aggregate and flocculate the cyanobacterial cells (Figure S3, Supporting Information), but not the algal cells (Figure 2B for CR, Figure S1, Supporting Information, for $D Q)$. The cyanobacterial $S E$ cells aggregated immediately after addition of $\mathrm{B}-\mathrm{PEI}_{12}$ and $\mathrm{PEI}_{1.1}$, and the aggregates became larger with time (Figure 3A for B-PEI 12 , Figure S4A, Supporting Information, for $\left.\mathrm{B}-\mathrm{PEI}_{1.1}\right)$. B-PEI $\mathrm{P}_{0.5}$ induced only weak $S E$ aggregation (Figures S3 and S5A, Supporting Information). The SE cells in the aggregates have no visible damage, and the intracellular photosynthetic pigments were not depleted during 72-h exposure to B-PEIs, suggesting that these cells remained viable. B-PEIs did not only aggregate $S E$ cells, but also effectively flocculated them and accelerated their settling down (Figure 3C). Similarly, B-PEI 12 and $\mathrm{B}-\mathrm{PEI}_{1.1}$ induced aggregation of cyanobacterial $\mathrm{MA}$ cells (Figure $3 \mathrm{~B}$ for $\mathrm{B}-\mathrm{PEI}_{12}$ and Figure S4B, Supporting Information, for B-PEI ${ }_{1.1}$ ), but B-PEI ${ }_{0.5}$ did not (Figures S3 and S5B, Supporting Information). B-PEI 12 formed large compact aggregates of MA cells immediately after addition and the $M A$ cells aggregates were autofluorescent without visible damages. In contrast to $S E$, the 
A.

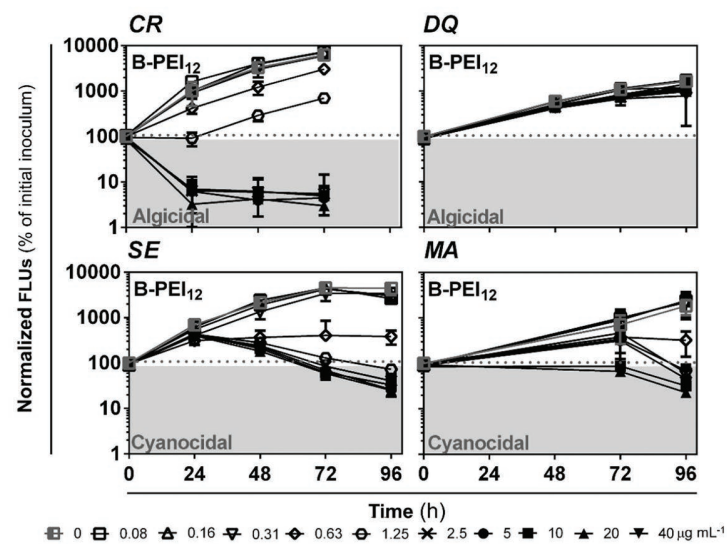

B.

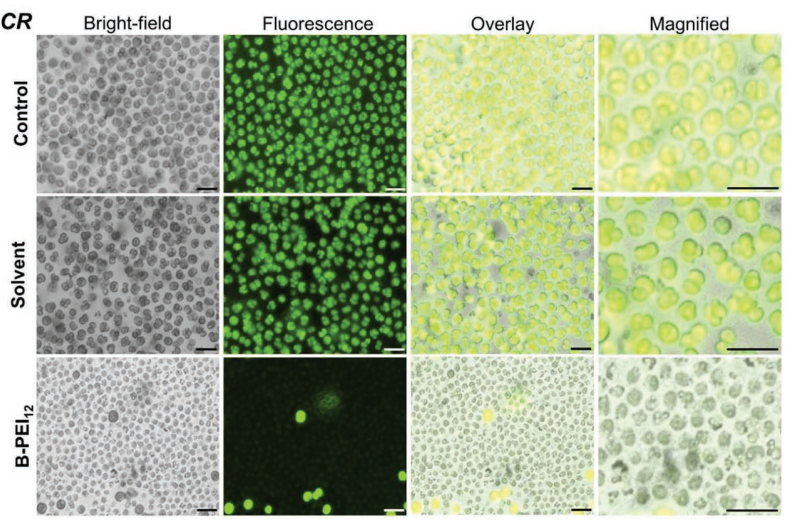

Figure 2. Cidal activity of $\mathrm{B}$-PEls to algae $C R$, but not to algae $D Q$ and cyanobacteria $S E$ and MA. A) B-PEI ${ }_{12}$ effects against algae Chlamydomonas reinhardtii $(C R)$ and Desmodesmus quadricauda $(D Q)$ and cyanobacteria Synechococcus elongatus (SE) and Microcystis aeruginosa (MA) as assessed by autofluorescence at different time points. Data are expressed as a percentage of fluorescence units (FLUs) for initial inoculum and presented as means (SD). B) CR cells after treatment with B-PEI ${ }_{12}$. Representative bright field, fluorescence, and overlaid images of non-treated $C R$ cells (naïve and solvent controls) and CR cells treated with $\mathrm{B}-\mathrm{PEI}_{12}$ at the concentration of $20 \mu \mathrm{g} \mathrm{mL}^{-1}$ for $72 \mathrm{~h}$. Scale bar $=20 \mu \mathrm{m}$.

flocs of MA cells did not settle, but they floated in medium near to its surface (Figure 3C).

Selective aggregation activity of B-PEIs to cyanobacterial cells over algal cells remained also in their mixed culture. In the mixed culture of cyanobacteria $S E$ and algae $C R$, the cyanobacterial $S E$ cells were aggregated, but the algal $C R$ cells remained dispersed (Figure 4), suggesting that B-PEIs are species-selective aggregating and flocculating agents. Similar to the individual cultures, only the $C R$ cells were deformed, fragmented, and less autofluorescent in response to polymer treatment, suggesting that B-PEIs are also selective cidal agents.

One possible mechanism of the B-PEIs to induce aggregation is that the B-PEI polymer chains bridge two or more cyanobacterial cells. However, because the MWs of B-PEIs used in this study are relatively low, the polymer chains may be too short for bridging cells. Alternatively, the PEIs may cause aggregation of cyanobacteria by the electrostatic patching mechanism. ${ }^{[24]}$ When B-PEIs bind to the surfaces of SE or MA cells, they may form cationic patches or zones, which attract the anionic surfaces of other cells and cause cell aggregation, ultimately leading to flocculation. ${ }^{[6 a]}$ The results indicated that B-PEIs with higher MW induce aggregation of SE cells more effectively. We speculate that the high MW B-PEIs have larger numbers of cationic ammonium groups per molecule, which provides more contact points or more cationic charges for electrostatic binding to anionic bacterial surfaces. Therefore, the high MW B-PEI polymer chains were likely to create highly cationic patches on the cell surfaces, thus inducing cell attachment more effectively.

The electrostatic patching mechanism also requires a close contact between cell surfaces for aggregation. Indeed, the $S E$ cells in the flocs were connected, and the flocs were compact as confirmed by microscopy (Figure 3A). The SE flocs settled by gravity after addition of the B-PEIs, and most cells appear to be settled down (clear supernatant with no green color, Figure $3 \mathrm{C}$ ). In contrast, compact flocs of MA cells with the similar size as those of SE cells (Figure 3) floated near the surface of culture medium (Figure 3C), which may be attributed to the presence of gas vesicles in $M A$ cells $^{[25]}$ making the MA flocs buoyant. B-PEI-induced aggregation and flocculation appear to mimic the naturally occurred formation of free-floating bloom (dense aggregates of cells) in the environment, which is well known for this harmful cyanobacterium. ${ }^{\text {26a] }}$

As discussed above, B-PEIs act most likely directly by interacting with individual cells which leads, in the case of cyanobacterial species, to cell clustering. This cell aggregation may be related to observed growth-inhibitory effects of B-PEIs on studied species. The cell aggregation is frequently observed in many photosynthetic microorganisms and represents one of their important adaptive reactions to excess light by selfshading. ${ }^{[26]}$ For example, chemically induced aggregation of $C R$ cells by glyco-dendrimer coated gold nanoparticles decreased light absorption due to enhanced cell packing and self-shading, thus subsequently decreased photosynthesis. ${ }^{[27]}$ Therefore, the aggregation of $S E$ and $M A$ cells induced by the B-PEIs might also reduce their photosynthesis, leading to growth inhibition. Moreover, cellular aggregation is also likely to decrease cellular exchange of nutrients and wastes with the external environment due to limited diffusion of these molecules in the aggregates and induce the formation of an anoxic zone within large aggregates ${ }^{[28]}$ Therefore, it is possible that the PEIinduced aggregation of cyanobacterial cells prevents efficient photosynthesis and cell metabolism, which contributes to the growth-inhibitory effect of B-PEIs. However, there is no direct correlation between the aggregation activity and growth-inhibitory effects of B-PEIs. Low MW B-PEI ${ }_{0.5}$ did not cause cellular aggregation of $M A$ cells, but the $\mathrm{IC}_{50}$ values were similar to those of higher MW B-PEI 1.1 and $\mathrm{B}-\mathrm{PEI}_{12}$ that induced significant aggregation. Thus, the cellular aggregation may contribute to the growth inhibition, but not likely to be a primary mode of action for B-PEIs.

\subsection{Anti-Algal and Anti-Cyanobacterial Activities and Polymer Structure}

It has been reported that the antibacterial property of synthetic polymers including hydrophilic polycationic polymers increases 

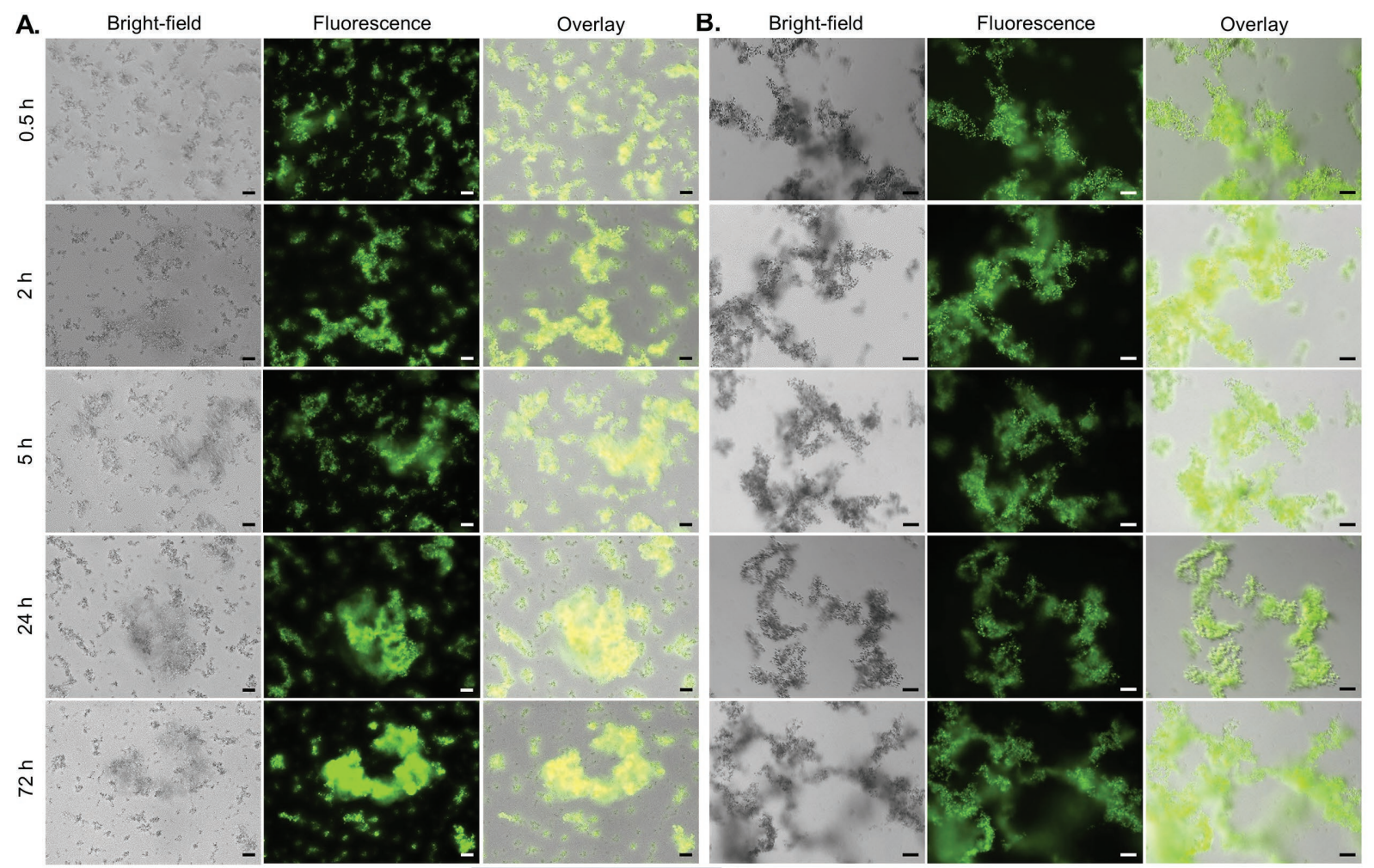

C.
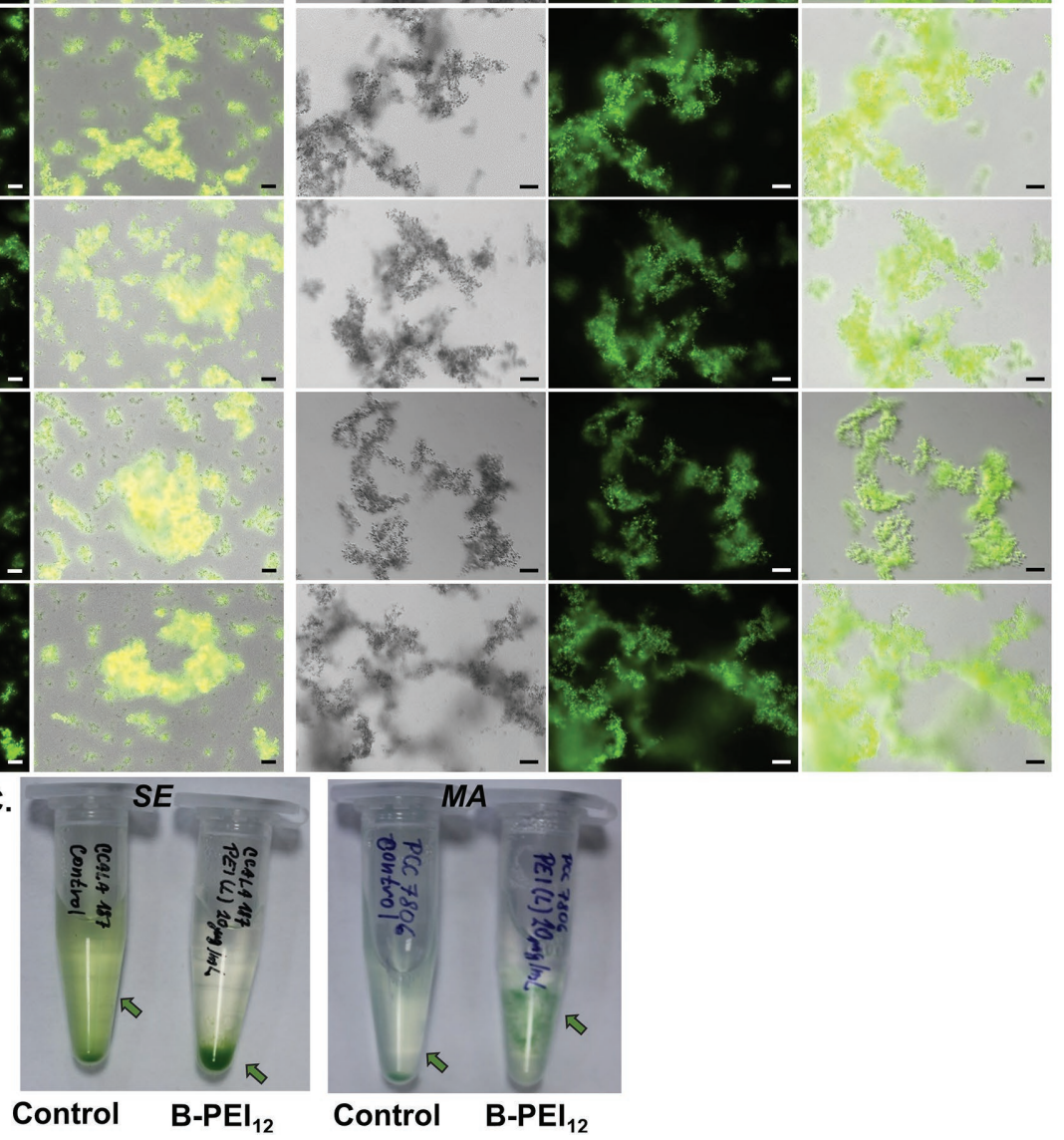

Figure 3. Aggregation and flocculation activity of $B-P E I_{12}$ inducing clustering of cyanobacterial cells. A,B) Time-dependency of aggregation activity. Representative bright-field, fluorescence, and overlaid images of cyanobacteria Synechococcus elongatus (SE) (A) and Microcystis aeruginosa (MA) (B) treated with B-PEI12 at the concentration of $20 \mu \mathrm{g} \mathrm{mL} \mathrm{L}^{-1}$ for $0.5,2,5,24$, and $72 \mathrm{~h}$. The aggregated cells (flocs) were still autofluorescent, suggesting the presence of live cells with intact photosynthetic pigments in the aggregates. Scale bar $=20 \mu \mathrm{m}(S E) / 50 \mu \mathrm{m}(\mathrm{MA})$. C) Flocculation activity of $\mathrm{B}-\mathrm{PEI}_{12}$ at the concentration of $20 \mu \mathrm{g} \mathrm{mL} \mathrm{L}^{-1}$ inducing clustering of cyanobacterial cells. The flocs of SE cells settled down while the flocs of MA cells floated close to the culture medium surface.

with MW when the MW is lower than $50 \mathrm{kDa} .{ }^{[29]}$ However, in this study, the $\mathrm{IC}_{50}$ values of all B-PEIs against $C R, M A$, and $S E$ were within a narrow range $\left(0.1-0.6 \mu \mathrm{g} \mathrm{mL}{ }^{-1}\right)$, although the MWs were significantly different $\left(\overline{\mathrm{M}}_{n}=0.5,1.1\right.$, and $\left.12 \mathrm{kDa}\right)$. Although the apparent activity of each molecule was higher for the B-PEIs with higher MWs (the $\mathrm{IC}_{50}$ values given in molarity are smaller for them-Table S2B, Supporting Information), the similar $\mathrm{IC}_{50}$ values in $\mu \mathrm{g} \mathrm{mL} \mathrm{m}^{-1}$ suggest that the total number of cationic groups in solution is important for the growth inhibition of these cells, rather than the size of polymers, similar to their bacteriostatic activity against Gram-positive bacterium $S A{ }^{[8]}$ The cidal activities of B-PEIs against algae $C R$ did not increase with increasing MW either (Table 1). In contrast, the aggregation and flocculation activities were highly dependent on the MW of B-PEIs. The ability of B-PEI with low MW to aggregate both cyanobacterial species and subsequently flocculate them appeared rather limited as also reported for B-PEIs and cyanobacterium $A F^{[22 a]}$ or Gram-negative bacterium $S O$ MR-1. ${ }^{[23]}$ This implies the existence of a minimum MW or charge density for cyanobacterial aggregation and flocculation to occur, a feature usually related to a physical patching mechanism. ${ }^{[30]}$

We further assessed how is the presented activity of B-PEIs specific to their chemical structure (ethylene imine:-C-C-N-). Low MW PPI-DEN (MW = 317, propylene imine structure: $-\mathrm{C}-\mathrm{C}-\mathrm{C}-\mathrm{N}-$, Figure $5 \mathrm{~A}$ ) showed similar anti-cyanobacterial and anti-algae effects as low MW B-PEI 0.5 $\left(\overline{\mathrm{M}}_{n}=470\right.$, ethylene imine structure: $\left.-\mathrm{C}-\mathrm{C}-\mathrm{N}-\right)$. PPI-DEN inhibited the growth of both algae and cyanobacteria with similar IC $_{50}$ values to those for B-PEIs (Table 1, Figure 5B) and induced a weak aggregation of $S E$ cells, but not those of other species (Figure 6) similar to $\mathrm{B}-\mathrm{PEI}_{0.5}$. Interestingly, PPI-DEN was cidal against all tested species except for SE (Figure 5C), while B-PEIs showed a cidal effect against $C R$ only. The 

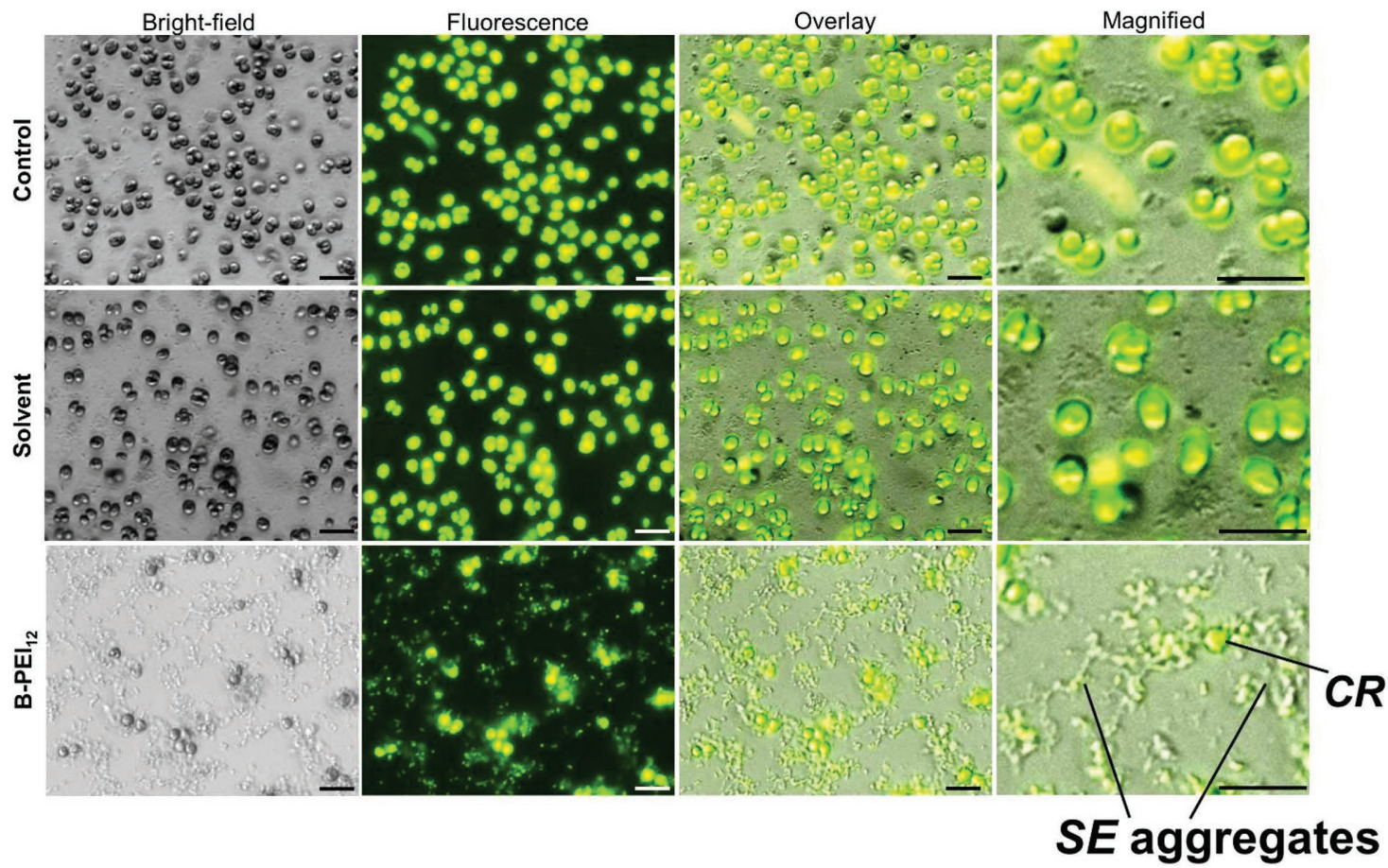

Figure 4. Selective aggregation activity of $\mathrm{B}-\mathrm{PEI}{ }_{12}$ to cyanobacterial cells over algal cells. Representative bright-field, fluorescence, and overlaid images of cyanobacterium Synechococcus elongatus (SE) and Chlamydomonas reinhardtii (CR) treated with B-PEl 12 at the concentration of $20 \mu \mathrm{g} \mathrm{mL} \mathrm{L}^{-1}$ for $72 \mathrm{~h}$. B-PEI 12 selectively aggregated $S E$ cells as well as selectively deformed and fragmented $C R$ cells. The aggregated cells (flocs) of $S E$ cells were still autofluorescent, suggesting the presence of live cells with intact photosynthetic pigments in the aggregates. $C R$ cells were damaged and less autofluorescent than control cells. Scale bar $=20 \mu \mathrm{m}$.

differences in a cidal activity between PPI-DEN and B-PEI may suggest that not only cationic charges, but also the chemical structures or overall molecular properties are important determinants for anti-cyanobacterial and anti-algae activities of polymers. Comparing the chemical structures of PPI-DEN and B-PEI molecules, the striking difference is that PPI-DEN has a well-defined structure and lacks secondary ammonium groups. It has been reported that the formation of global cationic amphiphilic structures is important for antimicrobial activity of small molecules. ${ }^{[31]}$ PPI-DEN has a chemical structure with cationic amphiphilicity consisting of peripheral cationic primary ammonium $(\mathrm{pKa} \approx 10.0$ ) groups and internal tertiary amines $(\mathrm{pKa} \approx 6.0)^{[32]}$ which may act as non-ionic groups and interact well with the hydrophobic domains of cell membranes. In contrast, B-PEI does not have such a defined cationic amphiphilic structure due to undefined branched structures in which the cationic (primary and secondary ammoniums) and non-ionic (tertiary amine) groups are not segregated well. The cationic amphiphilic structure of PPI-DEN may facilitate the insertion to cell membranes, thus causing membrane disruption more efficiently than B-PEI.

Algicidal activity of PPI-DEN against $C R$ was similar to that of B-PEIs, inhibiting quickly cell motility during the first hour of exposure (data not shown) and later on decreasing the number of compact fluorescent cells and increasing that of less autofluorescent, permanently deformed, and fragmented cells (Figure 6A). Algicidal activity of PPI-DEN against $D Q$ and $M A$ was slower (Figure 5C). Exposed DQ and MA (Figure 6) cells were less autofluorescent suggesting a decrease of an amount of photosynthetic pigments, but remained intact. PPI-DEN may target photosynthesis leading to chlorotic cells lacking photosynthetic pigments such as chlorophylls, carotenoids, or phycobiliproteins. We suggest that a mechanism of cidal activity of PPI-DEN involves binding and internalization into the treated algal and cyanobacterial cells similar to the cationic PAMAM dendrimers. ${ }^{[19 c]}$ The cationic PAMAM dendrimers also modulate photosynthesis probably by an oxidative breakdown of photosynthetic pigments due to the generation of reactive oxygen species. ${ }^{[19]}$ Similar mechanism may also be relevant for PPI-DEN.

\section{Conclusions}

In this study, we investigated the anti-algal and anti-cyanobacterial activities of B-PEIs against selected algae $(C R$ and $D Q)$ and cyanobacteria (MA and $S E$ ) and their ability to induce aggregation and flocculation of these aquatic phototrophic microorganisms. We demonstrate that B-PEIs selectively interact with algal and cyanobacterial cells and have dual-functionality and selectivity (Scheme 1). The B-PEIs caused selective cell death to algal species $C R$ (cidal activity), but they inhibited growth of other phototrophic microorganisms without causing death (static activity). The B-PEIs selectively induced cellular aggregation and flocculation of cyanobacteria $M A$ and $S E$, but not algae $C R$ and $D Q$. Interestingly, the growth-inhibitory and cidal effects were not related to $\mathrm{MW}$, but the ability to aggregate and flocculate cyanobacteria was. 


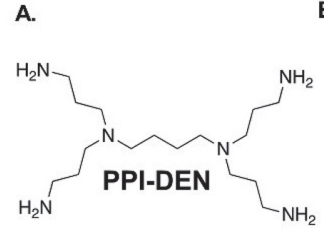

B.

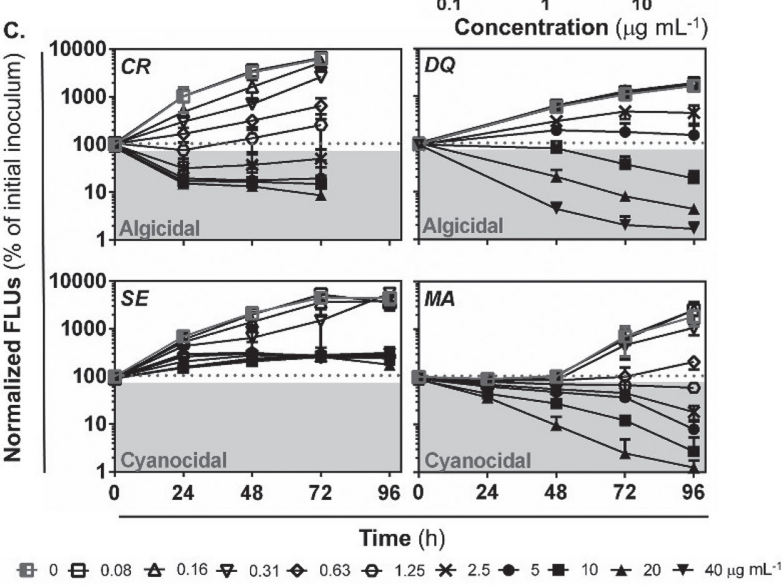

Figure 5. Anti-algal and anti-cyanobacterial activities of PPI-DEN. A) Chemical structure of PPI-DEN. B) The effects of PPI-DEN on the growth of algae Chlamydomonas reinhardtii $(C R)$ and Desmodesmus quadricauda $(D Q)$ and cyanobacteria Synechococcus elongatus (SE) and Microcystis aeruginosa $(M A)$ after $72 \mathrm{~h}$. Data are expressed as a percentage of a nontreated control. C) PPI-DEN against algae $C R$ and $D Q$ and cyanobacteria $S E$ and $M A$ as assessed by autofluorescence at different time points. Data are expressed as a percentage of fluorescence units (FLUs) for initial inoculum and presented as means (SD).

B-PEIs have been widely studied for biomedical applications including DNA-delivery carriers and antimicrobial agents against biomedically related microorganisms ( $E C, S A$, etc.). Our study indicates that B-PEIs are potent antimicrobials effective in controlling the growth of environmentally relevant algae and cyanobacteria and may be useful as effective and selective chemical flocculants of cyanobacteria in water treatment operations and biotechnological processes. The cyanobacterial cells were found intact at low concentrations of B-PEIs $\left(<20 \mu \mathrm{g} \mathrm{mL} \mathrm{m}^{-1}\right)$, therefore, the target cyanobacteria can be likely removed without causing a release of intracellular toxins. In addition, the flocs of $S E$ cells by B-PEIs settled down, but that of MA cells floated (Figure 3C). Thus, SE cells can be separated or harvested by using B-PEIs to force them to form lumps and settle down and MA cells to make them float on the surface of medium and be removed as a scum.

Since B-PEIs act as cidal agents only with $C R$, the selective activity of B-PEIs may also allow the selective control of growth of target phototrophic microorganisms. In addition, the cationic polymer analog PPI-DEN with similar growth-inhibitory effects as B-PEIs was cidal to the most of phototrophic microorganisms, while the B-PEIs only to $C R$. Although they have similar branched cationic chemical structures, the difference in the chemical structure or overall molecular properties appears to result in the different cell selectivity of their cidal activity. We envision that use of a combination of different polymers may allow the selective growth control and removal of algae and cyanobacteria, which has a great potential for treating health, environmental, and technical issues of phototrophic microorganisms and can be applicable in many systems during water treatment operations and biotechnological processes. However, because B-PEIs are likely relatively stable and slowly biodegradable, anti-algal and anti-cyanobacterial activities of more environmentally friendly B-PEI analogs, such as grafting chitosan with PEIs, should be evaluated along with the effects of important external environmental factors, such as the $\mathrm{pH}$, dose, ionic strength, and temperature, on dual-functionality of B-PEIs and their analogs. Specifically, high monovalent $\left(\mathrm{Na}^{+}, \mathrm{NaCl}\right.$ $>100 \mathrm{~mm})$ and divalent $\left(\mathrm{Ca}^{2+}\right.$ or $\mathrm{Mg}^{2+}, \mathrm{CaCl}_{2}$ or $\left.\mathrm{MgCl}_{2}>1 \mathrm{~mm}\right)$ salt concentrations have been reported to interfere with antimicrobial activity of cationic peptides or polymers ${ }^{[33]}$ because high ionic strength reduces the electrostatic to microbial cells. Natural or industrial waters contain a broader range of different ions and concentrations. It would be of our future interest to determine the anti-algal and anti-cyanobacterial activities of B-PEIs under conditions related to their potential applications.

\section{Experimental Section}

Materials: B-PEls such as B-PEI 0.5 (cat. no. 02371, lot no. 55832), B-PEI ${ }_{1.1}$ (cat. no. 06089, lot no. 559792), and B-PEI 12 (cat. no. 19850, lot no. 579738) were purchased from Polysciences, Inc. (Warrington, PA). They were previously characterized by potentiometric titration, GPC, reverse-phase HPLC, dynamic light scattering, and NMR analysis ${ }^{[8 b]}$ (polymer characteristics in Table S1, Supporting Information, polymer structure in Figure 1E). Low MW PPI-DEN (cat. no. 460699), a dendrimer of first generation with a diaminobutane core, four primary amine end groups, and two interior tertiary amines, was purchased from Sigma-Aldrich (Prague, Czech Republic). All polymers were used without further purification.

Algal and Cyanobacterial Cultures: Freshwater green algae $C R$ and $D Q$ which are commonly used as model organisms for anti-algal and biofouling studies were selected. ${ }^{[12,34]}$ These species are ubiquitous in natural or industrial water systems and commonly occur in extensive water blooms. ${ }^{[34]}$ Cyanobacteria SE and MA were used as common freshwater cyanobacteria and typical model species. MA is a globally occurring major bloom-forming cyanobacterium and also a producer of potent cyanotoxins microcystins, which pose human health and ecological risks ${ }^{[35]}$ (cell structures and environmental relevancies of all tested species in Table 1 and Table S3, Supporting Information).

The cultures of green algae CR CCALA 928 and DQ CCALA 463 and those of cyanobacterium SE CCALA 187 were provided from Culture Collection of Autotrophic Organisms (CCALA, Trebon, Czech Republic). The culture of cyanobacterium MA PCC 7806 was provided by the Pasteur Culture Collection of Cyanobacteria (Institute Pasteur of Paris, Paris, France). All cultures were continuously cultivated in Erlenmayer flasks in 50\% Zehnder Bold's basal (ZBB) medium (freshwater-based medium, $\mathrm{pH} 7.1$, salinity $<0.05 \%$, conductivity $725 \mu \mathrm{S} \mathrm{cm}^{-1}, \mathrm{Na}^{+}: 2.3 \mathrm{~mm}, \mathrm{Ca}^{2+}$. $\left.0.1 \mathrm{~mm}, \mathrm{Mg}^{2+}: 0.1 \mathrm{~mm}\right)$. The ZBB medium was prepared by mixing a medium Z (Zehnder[36]) with BB medium (Bold's basal medium ${ }^{[37]}$ ) in a ratio of $1: 1$, autoclaving, and subsequent diluting by sterile ultrapure water to $50 \%$. The algal and cyanobacterial cultures were grown under permanent illumination provided by cool white fluorescent tubes (Philips $36 \mathrm{~W} / 33,1500 \mathrm{~lx}$ ) at a temperature of $21 \pm 1{ }^{\circ} \mathrm{C}$ and aerated with sterilized air by passing through $0.22 \mu \mathrm{m}$ PES filter (Labicom, Olomouc, Czech Republic). Once a week, one half of the volume of a cell suspension was replaced by fresh sterile $50 \%$ ZBB medium.

The population doubling time of each algal and cyanobacterial culture was estimated from the growth curve under the assay conditions (Figure $1 \mathrm{~A}$ ) and was $19 \mathrm{~h}$ for $C R, 26 \mathrm{~h}$ for $D Q, 14 \mathrm{~h}$ for $S E$, and $27 \mathrm{~h}$ for $M A$. The growth of phototrophic microbial species was slower than 
A.

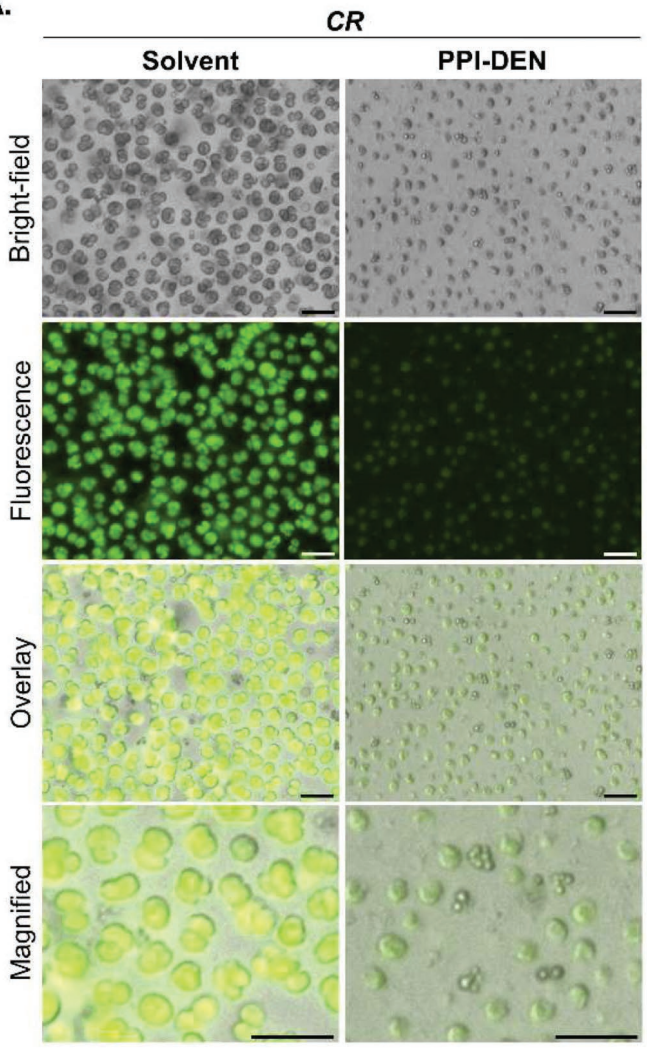

B.

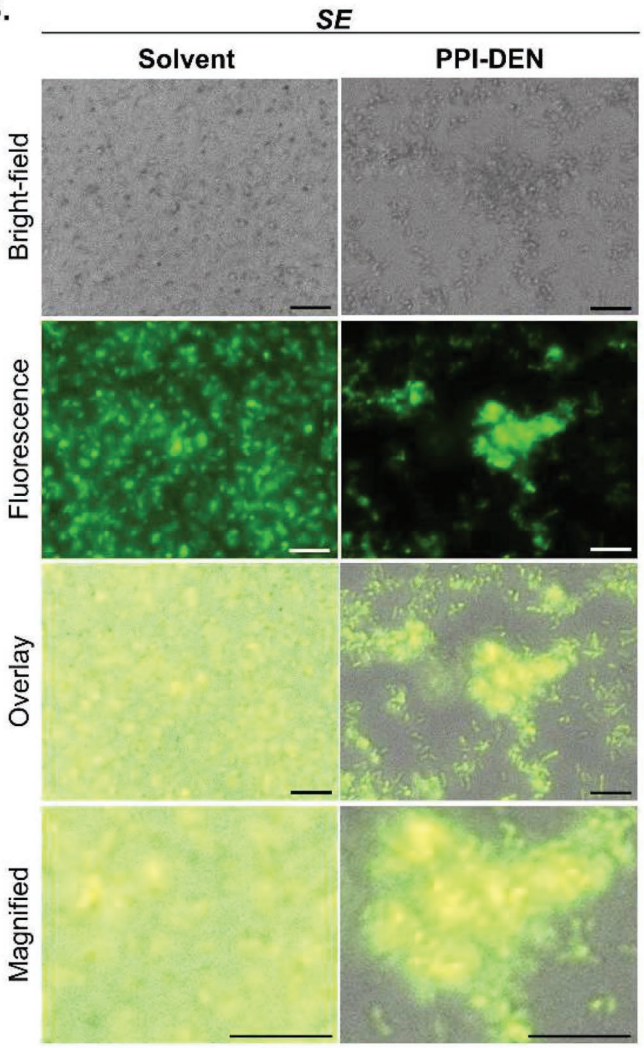

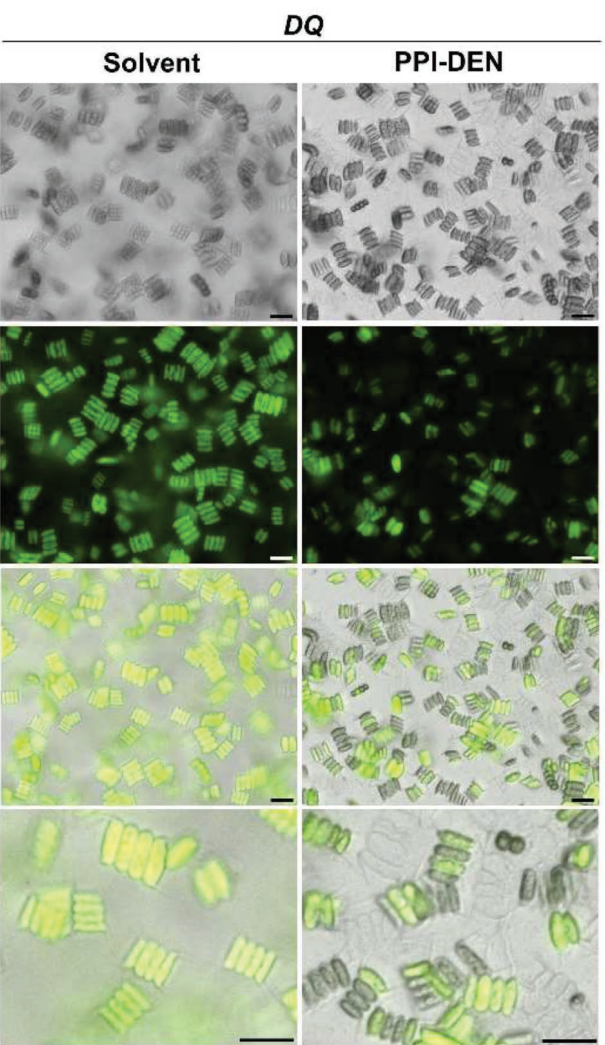
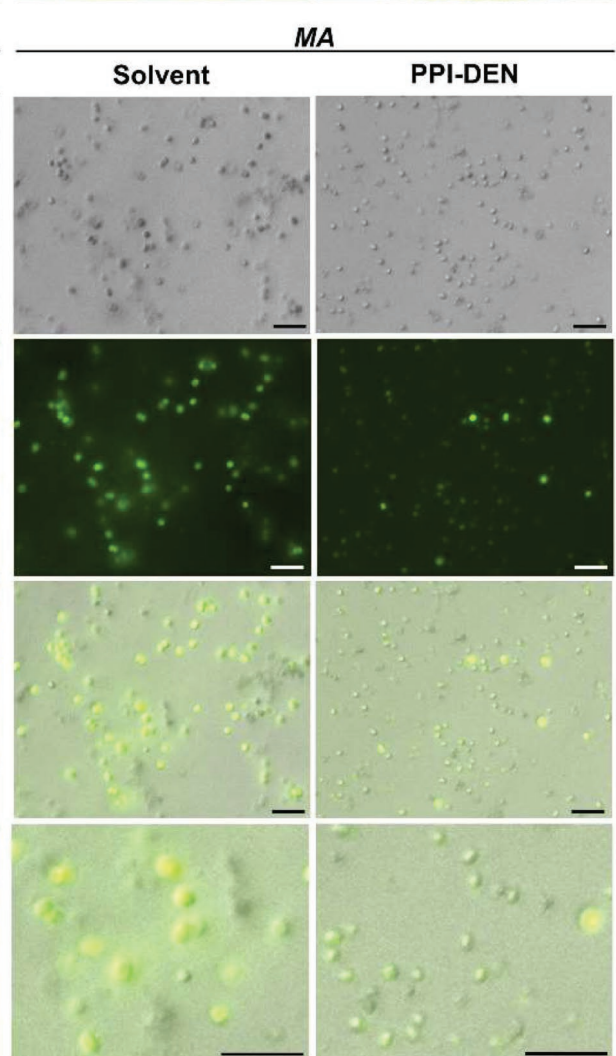

Figure 6. Algae $C R$ and $D Q$ and cyanobacteria $S E$ and $M A$ after treatment with PPI-DEN. Representative bright-field, fluorescence, and overlaid images of non-treated cells (solvent control) and cells treated with PPI-DEN at the concentration of $20 \mu \mathrm{g} \mathrm{mL}^{-1}$ for $72 \mathrm{~h}$. CR, Chlamydomonas reinhardtii, DQ, Desmodesmus quadricauda, MA, Microcystis aeruginosa, SE, Synechococcus elongatus. Scale bar $=20 \mu \mathrm{m}$ for $C R, D Q, M A / 10 \mu \mathrm{m}$ for $S E$. 

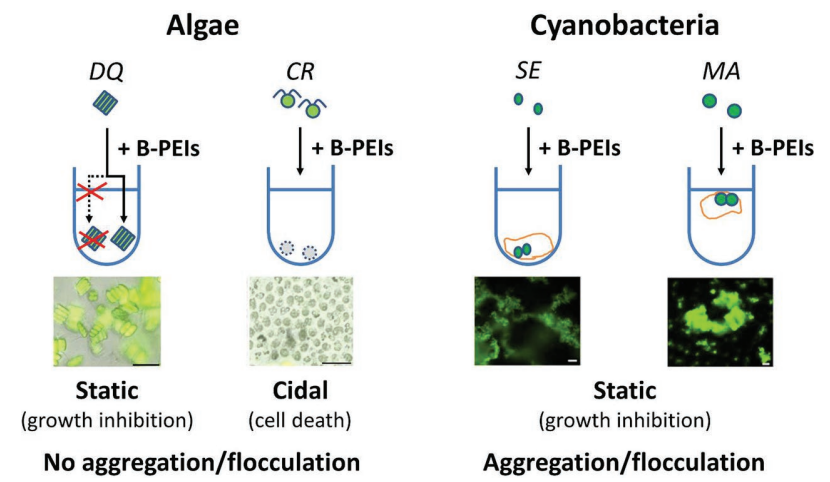

Scheme 1. Selective interactions of B-PEls with algal and cyanobacterial cells.

that of potentially human pathogenic bacteria SA and EC (doubling time $<1 \mathrm{~h}$ ), reflecting the longer incubation times (up to $96 \mathrm{~h}$ ) for all experimental assays.

Growth Activity: To evaluate antimicrobial activity of tested polymers, the growth inhibition assay was conducted in sterile 96 -well microplates (cat. no. 655201, Greiner Bio-One, Kremsmünster, Austria) made from polypropylene minimizing the risk of possible non-specific adsorption of studied polymers. Suspensions of microbial cells that reached the exponential growth phase were taken and diluted by freshly prepared sterile $50 \%$ ZBB medium. Working solutions of polymers were prepared from the stock solutions by diluting with $0.01 \%$ acetic acid. A range of experimental polymer concentrations varied from 0.08 to $40 \mu \mathrm{g} \mathrm{mL}$. The inoculum of both algal species was $\approx 1 \times 10^{6}$ cells $\mathrm{mL}^{-1}$, the initial concentration of both cyanobacterial species was tenfold higher, that is, $\approx 1 \times 10^{7}$ cells $\mathrm{mL}^{-1}$ (because of lower cell surface and volume of tested cyanobacterial species than those of algal species, ${ }^{[14]}$ Table S3, Supporting Information). On each microtiter plate, three different controls were included: 1) only polymer solution in medium, 2) microbial growth control in medium without polymer, and 3) microbial growth control in solvent control (final concentration of acetic acid: 0.001 vol\%). The microorganisms were grown under permanent illumination provided by cool white fluorescent tubes (Philips $36 \mathrm{~W} / 33,1500 \mathrm{~lx}$ ) at a temperature of $21 \pm 1{ }^{\circ} \mathrm{C}$ without shaking. Once a day, content of all wells was manually aerated by mixing with multichannel pipette. The optical density $(\lambda=680 \mathrm{~nm})$ was measured at the beginning of the experiments $\left(\mathrm{TO}^{\prime}\right)$ as well as after $24,48,72$, or $96 \mathrm{~h}\left(\mathrm{~T}^{2} 4^{\prime}, \mathrm{T} 48^{\prime}, \mathrm{T} 72^{\prime}\right.$, T96') by Synergy MX microplate reader (Biotek, Winooski, Vermont). T24' was not evaluated for $D Q$ and MA cultures because of their relatively slow growth (Figure $1 \mathrm{~A}$ ).

Algicidal/Cyanocidal Activity: The experimental setup was the same as that for the assessment of growth-inhibitory activity. To assess a decline of cell numbers below initial inoculum -indicating algicidal or cyanocidal activityautofluorescence of photosynthetic pigments $\left(\lambda_{\mathrm{ex}}=485 \mathrm{~nm} / \lambda_{\mathrm{em}}=675 \mathrm{~nm}\right.$ for green algae and $\lambda_{\mathrm{ex}}=590 \mathrm{~nm} / \lambda_{\mathrm{em}}=675 \mathrm{~nm}$ for cyanobacteria) was monitored using Synergy MX microplate reader (Biotek).

Aggregation/Flocculation Activity and Morphology Assessment: Aggregation and flocculation of algal or cyanobacterial cells in the presence of polymers and possible morphological changes were assessed by microscopy using upright fluorescence microscope Zeiss Axio Observer Z1 coupled to digital camera AxioCam 503 Mono (Zeiss, Jena, Germany). Non-stained samples were observed in the bright field or in fluorescence regime using Zeiss filter set No. 05 (consisting of a 395-440-nm band-pass excitation filter, a 460-nm beam splitter, and a 470-nm long-pass emission filter BPem ${ }^{-1}$. 470 LP)

Data Analysis and Statistics: Each experiment was repeated at least three times. In the growth inhibition assays, optical readings were normalized so that untreated control has $100 \%$ growth and the readings at $\mathrm{TO}^{\prime}$ were considered as $0 \%$ growth. A growth of the treated microorganisms was compared to that of non-treated control for each exposure time and data are expressed as a percentage of a non-treated control. In algicidal/cyanocidal activity assays, fluorescence readings were normalized to the autofluorescence of inoculated cells at $\mathrm{TO}^{\prime}$ and data are expressed as a percentage of fluorescence units (FLUs) for the initial inoculum.

Non-linear curve fitting to calculate $I C_{50}$ values was done using GraphPad Prism 6 software. The $I_{50}$ values (the concentration of polymer causing a $50 \%$ inhibition of the algal or cyanobacterial growth) were derived for each experiment, and the final I $C_{50}$ value was calculated as geo-mean with $95 \% \mathrm{Cl}$ (confidence interval). Minimum cidal concentration (MCC) was determined as the lowest concentration which significantly decreased autofluorescence below that of initial inoculation. One-way ANOVA with Dunnett's method (multiple comparisons vs control group) or with Tukey's method (multiple comparison) and twotailed unpaired $t$-test were done in GraphPad Prism 6. In all statistics, $p$-values less than or equal to 0.05 were considered significant.

\section{Supporting Information}

Supporting Information is available from the Wiley Online Library or from the author.

\section{Acknowledgements}

This research was supported by the RECETOX Research Infrastructure (LM2015051 and CZ.02.1.01/0.0/0.0/16 013/0001761) and by the Department of Biologic and Materials Sciences, School of Dentistry, University of Michigan, and JSPS Postdoctoral Fellowships for Research Abroad (No. 26-774 to H.T.). The authors thank Hana Klimova for the help with aggregation and flocculation activities and morphology assessment.

\section{Conflict of Interest}

The authors declare no conflict of interest.

\section{Keywords}

algae, antimicrobials, cyanobacteria, flocculants, poly(ethylene imine)s

Received: May 22, 2018

Revised: July 17, 2018

Published online: August 29, 2018

[1] a) World Health Organization, in Guidelines for Safe Recreational Water Environments (Eds.: WHO), Geneva, Switzerland 2003, 136; b) W. Han, W. Clarke, S. Pratt, Waste Manag. 2014, 34, 1148.

[2] H. C. P. Matthijs, D. Jancula, P. M. Visser, B. Marsalek, Aquat. Ecol. 2016, 50, 443.

[3] T. Hauer, P. Capek, P. Bohmova, Folia Microbiol. 2016, 61, 255.

[4] M. E. Callow, R. G. V. Edyvean, in Introduction to Applied Phycology (Ed: I. Akatsuka), SPB Academic Publishing, Hague, Netherlands 1990, p. 369

[5] a) M. H. Dehghani, J. Mol. Liq. 2016, 222, 1109; b) M. R. Sengco, D. M. Anderson, J. Eukaryot. Microbiol. 2004, 51, 169; c) D. M. Anderson, Ocean Coast. Manag. 2009, 52, 342; d) D. P. Hamilton, N. Salmaso, H. W. Paerl, Aquat. Ecol. 2016, 50, 351.

[6] a) C. S. Lee, J. Robinson, M. F. Chong, Process Saf. Environ. Prot. 2014, 92, 489; b) M. W. Tenney, W. F. Echelberger, R. G. Schuessler, J. L. Pavoni, Appl. Microbiol. 1969, 18, 965. 
[7] P.-Y. Qian, Y. Xu, N. Fusetani, Biofouling 2010, 26, 223.

[8] a) C. Wiegand, M. Bauer, U.-C. Hipler, D. Fischer, Int. J. Pharm. 2013, 456, 165; b) K. A. Gibney, I. Sovadinova, A. I. Lopez, M. Urban, Z. Ridgway, G. A. Caputo, K. Kuroda, Macromol. Biosci. 2012, 12, 1279.

[9] a) V. Legrand, D. Hourdet, R. Audebert, D. Snidaro, Water Res. 1998, 32, 3662; b) B. A. Bolto, D. R. Dixon, S. R. Gray, H. Chee, P. J. Harbour, L. Ngoc, A. J. Ware, Water Sci. Technol. 1996, 34, 117.

[10] a) M. Cadotte, M.-E. Tellier, A. Blanco, E. Fuente, T. G. M. van de Ven, J. Paris, Can. J. Chem. Eng. 2007, 85, 240; b) E. Fuente, A. Blanco, C. Negro, M. A. Pelach, P. Mutje, J. Tijero, Ind. Eng. Chem. Res. 2005, 44, 5616

[11] a) J. J. Virgen-Ortiz, J. C. S. dos Santos, A. Berenguer-Murcia, O. Barbosa, R. C. Rodrigues, J. Mater. Chem. B 2017, 5, 7461; b) A. P. Pandey, K. K. Sawant, Mater. Sci. Eng. C 2016, 68, 904.

[12] C. R. Janssen, M. Vangheluwe, P. Van Sprang, in New Microbiotests for Routine Toxicity Screening and Biomonitoring (Eds: G. Persoone, C. Janssen, W. DeCoen), Springer, Boston, MA 2000, p. 27.

[13] a) E. C. de Oliveira-Filho, R. M. Lopes, F. J. R. Paumgartten, Chemosphere 2004, 56, 369; b) M. Drabkova, W. Admiraal, B. Marsalek, Environ. Sci. Technol. 2007, 41, 309; c) D. Jancula, M. Drabkova, J. Cerny, M. Karaskova, R. Korinkova, J. Rakusan, B. Marsalek, Environ. Toxicol. 2008, 23, 218.

[14] J. Sun, D. Liu, J. Plankton Res. 2003, 25, 1331.

[15] D. Umysova, M. Vitova, I. Douskova, K. Bisova, M. Hlavova, M. Cizkova, J. Machat, J. Doucha, V. Zachleder, BMC Plant Biol. 2009, 9, 58 .

[16] a) D. S. Domozych, M. Ciancia, J. U. Fangel, M. D. Mikkelsen, P. Ulvskov, W. G. T. Willats, Front. Plant Sci. 2012, 3, 82; b) J. Voigt, J. Woestemeyer, R. Frank, J. Biol. Chem. 2007, 282, 30381.

[17] a) M. F. Fiore, J. T. Trevors, Biometals 1994, 7, 83; b) U. J. Juergens, C. Martin, J. Weckesser, FEMS Microbiol. Lett. 1989, 65, 47; c) E. Hoiczyk, A. Hansel, J. Bacteriol. 2000, 182, 1191; d) E. Gantt, in The Molecular Biology of Cyanobacteria (Ed: D. A. Bryant), Springer, Dordrecht, Netherlands 2006, p. 119.

[18] a) N. B. Wyatt, L. M. Gloe, P. V. Brady, J. C. Hewson, A. M. Grillet, M. G. Hankins, P. I. Pohl, Biotechnol. Bioeng. 2012, 109, 493; b) J. Liu, Y. Zhu, Y. Tao, Y. Zhang, A. Li, T. Li, M. Sang, C. Zhang, Biotechnol. Biofuels 2013, 6, 98.

[19] a) A.-N. Petit, T. Debenest, P. Eullaffroy, F. Gagne, Nanotoxicology 2012, 6, 315; b) A.-N. Petit, P. Eullaffroy, T. Debenest, F. Gagne, Aquat. Toxicol. 2010, 100, 187; c) S. Gonzalo, I. Rodea-Palomares,
F. Leganes, E. Garcia-Calvo, R. Rosal, F. Fernandez-Pinas, Nanotoxicology 2015, 9, 706.

[20] a) I. Pouneva, Bulg. J. Plant Physiol. 1997, 23, 67; b) K. Schulze, D. A. Lopez, U. M. Tillich, M. Frohme, BMC Biotechnol. 2011, 11, 118; c) E.-M. Zetsche, F. J. R. Meysman, J. Plankton Res. 2012, 34, 493.

[21] I. M. Helander, H. L. Alakomi, K. Latva-Kala, P. Koski, Microbiology 1997, 143, 3193.

[22] a) M. J. Zeleznik, J. M. Segatta, L.-K. Ju, Enzyme Microb. Technol. 2002, 31, 949; b) S. A. Arrington, M. J. Zeleznik, D. W. Ott, L.-K. Ju, Enzyme Microb. Technol. 2003, 32, 290.

[23] M.-E. M. Krapf, B. Lartiges, C. Merlin, G. Francius, J. Ghanbaja, J. F. L. Duval, Colloids Surf. B Biointerfaces 2016, 139, 285.

[24] a) A. Pfau, W. Schrepp, D. Horn, Langmuir 1999, 15, 3219; b) D. Horn, Wochenbl. Papierfabr. 2001, 129, 1589; c) A. Blanco, E. Fuente, C. Negro, J. Tijero, Can. J. Chem. Eng. 2002, 80, 1.

[25] B. Y. Xu, Y. N. Dai, K. Zhou, Y. T. Liu, Q. Sun, Y. M. Ren, Y. Chen, C. Z. Zhou, Acta Crystallogr. D. Biol. Crystallogr. 2014, 70, 3013.

[26] a) J. Dervaux, A. Mejean, P. Brunet, PLoS One 2015, 10, e0120906; b) M. Koblizek, J. Komenda, J. Masojidek, L. Pechar, J. Phycol. 2000, 36, 662 .

[27] a) F. Perreault, N. Bogdan, M. Morin, J. Claverie, R. Popovic, Nanotoxicology 2012, 6, 109; b) C. Saison, F. Perreault, J.-C. Daigle, C. Fortin, J. Claverie, M. Morin, R. Popovic, Aquat. Toxicol. 2010, 96, 109.

[28] A. L. Shanks, M. L. Reeder, Mar. Ecol. Prog. Ser. 1993, 96, 43.

[29] a) E.-R. Kenawy, S. D. Worley, R. Broughton, Biomacromolecules 2007, 8, 1359; b) A. Strassburg, F. Kracke, J. Wenners, A. Jemeljanova, J. Kuepper, H. Petersen, J. C. Tiller, Macromol. Biosci. 2015, 15, 1710.

[30] B. Bolto, J. Gregory, Water Res. 2007, 41, 2301.

[31] a) S. Choi, A. Isaacs, D. Clements, D. Liu, H. Kim, R. W. Scott, J. D. Winkler, W. F. DeGrado, Proc. Natl. Acad. Sci. U. S. A. 2009, 106, 6968; b) E. F. Palermo, Sa. Vemparala, K. Kuroda, Biomacromolecules 2012, 13, 1632 .

[32] D. Cakara, M. Borkovec, Croat. Chem. Acta 2007, 80, 421.

[33] a) S. P. Liu, L. Zhou, R. Lakshminarayanan, R. W. Beuerman, Int. J. Pept. Res. Ther. 2010, 16, 199; b) I. Sovadinova, E. F. Palermo, M. Urban, P. Mpiga, G. A. Caputo, K. Kuroda, Polymers 2011, 3, 1512.

[34] M. Arora, in The Algae World (Eds: D. Sahoo, J. Seckbach), Springer, Dordrecht, Netherlands 2015, p. 91

[35] P. Babica, L. Blaha, B. Marsalek, J. Phycol. 2006, 42, 9.

[36] R. Staub, Schweiz. Z. Hydrol. 1961, 23, 83

[37] H. C. Bold, Bull. Torrey Bot. Club 1949, 76, 101. 